\title{
Reflections on Online Mathematics Teaching
}

\author{
Zerrin TOKER ${ }^{1}$, Didem BEKTAŞ ${ }^{2}$ \\ 1 TED University, zerrin.toker@tedu.edu.tr http://orcid.org/0000-0001-9660-0403 \\ 2 TED University, didem.bektas@tedu.edu.tr http://orcid.org/0000-0001-5048-7986
}

Received : 07.07.2021

Accepted : 13.09.2021

Doi: 10.17522/balikesirnef.964470

\begin{abstract}
A changing world and developing events have resulted in the elevation of online teaching to one of the most important topics on our agenda. The effectiveness of online teaching is related to a realization of certain basic elements; the main performers of which are teachers. The transition to online education is also a new learning process for teachers. For their new learning process, their perceptions regarding the new phenomenon is important in understanding their adaptation process. This study aims to investigate 'What kinds of metaphors do teachers produce to describe online mathematics teaching?'. The study is designed as phenomenology, and metaphor analysis was used in the analysis of the data. Forty-three teachers participated in this research. The participants expressed their ideas concerning online mathematics education using metaphors. Twenty-seven different metaphors and twenty-three different reasons were created from the thoughts of the participants. The most used metaphor was 'food', and the two most used explanations were 'need to progress in a certain program' and 'lack of interaction/communication in the process'. The results of the study reveal that mathematics teachers have different perceptions in regard to emergency online education.
\end{abstract}

Keywords: Online education, online mathematics learning, metaphor analysis, pandemic.

Corresponding author: First Name, last name, address, or anything to notify reader (supporting institution or Grant, etc.)

\section{Introduction}

Online courses have become one of the most important topics of our lives and the agenda we follow as a result of today's conditions. The teaching system, which includes learning over the Internet, is called online education (Karakaş, 2020). There are two types of online education; synchronous and asynchronous. Synchronous education is the simultaneous 
interaction of the students and the teacher, while asynchronous education is called the interaction of the teacher and the student at different times (Baki, Karal, Cebi, Şılbır, \& Pekşen, 2009). In this process, there are necessary materials for students and teachers to participate in education. These are the Internet, an electronic device (phone, computer, and suchlike), and an environment for study.

At the end of 2019, the Covid-19 virus spread all around the world in only a short time, changed our lifestyles, and affected education as it had in other areas. As a result of this, online education has become a concept that is now a serious item on the agenda of educators. After the first case was seen in Turkey, quarantine was implemented in a short time, and schools were initially placed on holiday. After this, face-to-face classes were suspended due to the prolongation of the process, and Information and Communication Technologies (ICT) (Bozkurt, 2015) based on the Internet, and other new technologies began started to work to provide much needed support for education. In this context, emergency online training brought about by the unexpected pandemic process has started to be implemented in Turkey, as well as throughout the rest of the world.

In the current literature, the benefits of online education, such as adaptability, active learning, and participation are emphasized, but at the same time, problems such as workload, student resistance and a decrease in students' interest in courses, as well as a lack of materials, are also discussed (Kebritchi, Lipschuetz, \& Santiague, 2017). In addition to the benefits of online education, restrictions to the teacher-student relationship is another problem (Karakus, Ucuzsatar, Karacaoglu, Esendemir, \& Bayraktar, 2020). For example, Elçil and Şahiner (2014) reveal that there are disconnections in teacher-student communication, as well as with university students who experience distractions and a lack of motivation during the online education process. On the other hand, Altiparmak, Kurt, and Kapidere (2011) identify possible technological problems and mention problems such as students not being ready for programs, and financial inadequacies. Teachers, on the other hand, state that it is difficult to communicate with students remotely, in addition to the difficulty of feeling restricted by technology (Hilli, 2020). One of the issues that cause negative results, such as worry, anxiety, and stress, is the uncertainty of the situation (Küçükkömürler, 2017). Another study on the online education process with classroom teachers reveals that this situation affects students in many areas (Duban \& Şen, 2020). Since students are educated at home, students do not have a certain sleep and study pattern, and some students do not have the opportunity to access education. Duban and Şen (2020) in their study, in which they state that students do not 
receive characteristics such as respect and sociability that they will benefit from in a classroom environment, in online education, show that online education similarly affects all teaching fields. According to Sümer's (2016) research, reasons such as the fact that the teacher-student relationship is limited to written communication in the online education process, and the inability to make eye contact, show the interaction problem between teacher and student. In research by Tuncer and Bahadir (2017), it is stated by students that lecturers were indifferent and not sincere during the process, and that the learning environment was not friendly.

While the online training process of mathematics teachers is similar to other teachers in certain subjects, it can also differ in a number of field-specific points. Ilgaz (2014) finds online education supportive in terms of the fact that lessons can accessed later. Similarly, Karasar (2004) emphasizes that online education brings convenience as well as being supportive. A study by Gürsul and Keser (2009) shows that online training is more successful than face-to-face training in group work, contrary to previous findings in the literature. One of the most important findings of Gürsul and Keser (2009) is that there is a statistically significant difference in the success levels of groups in the face-to-face and online problembased learning processes, mostly in favor of the online groups. For this reason, studies on online practices of mathematics teaching should be dealt with separately. A number of points may be associated with this, such as the nature of mathematics courses, practices, and student perceptions. It is frequently said that there are difficulties in the learning and teaching of mathematics in Turkey (Yenilmez \& Avcu, 2009). In addition to the fact that students see mathematics as a difficult and boring subject, most students describe mathematics using negative words, such as nightmare, fear, and stress (Tahiroğlu \& Çakır, 2014). In this case, it makes it difficult for students to be motivated in mathematics lessons. Certain materials or tools may be required (for example, the need to use a graphic tablet) to be able to solve questions in mathematics lessons and to reflect solutions to the students. The use of materials used in teaching mathematics is another challenging point that arises for mathematics teachers in online education. In addition, the technological readiness of teachers is one of the factors affecting this process.

The effectiveness of online teaching, whether it is an emergency or a choice in the normal teaching process, is closely-related to the realization of certain basic elements. The main performers of these basic elements are teachers. However, the transition to online education is also a new learning process for teachers. This process can be challenging and, at 
the same time, developing for teachers who are responsible for going beyond routine practices, designing new practices and integrating them into lessons, and doing all of this without any preparatory process. The findings of teachers' learning in the adaptation process to new practices reveal that this is related to teachers' reflective thoughts (Toker, 2021). These findings are also valid for mathematics teachers. In this context, it is important to hear the voice of teachers, who are the main actors of online teaching, towards teaching. The research question of the study is defined as 'What kinds of metaphors do teachers produce to describe online mathematics teaching?'. The term metaphor used in the research is used to compare a phenomenon to another phenomenon through its similar characteristics. Regarding the research question, sub-questions were formed concerned with planning, resource use, material use, methods used, classroom management, evaluation, feedback, and teachers' professional development.

\section{Conceptual Framework}

Metaphors are important representative tools in revealing people's perceptions and thoughts regarding a particular phenomenon. One of the main purposes of using metaphors in qualitative research is to reveal the current situation (Fırat, Kabakç1-Yurdakul, \& Ersoy, 2014). In this context, metaphors are used as a powerful data collection tool that can be used to determine perceptions and thoughts in recent studies. (Guveli, İpek, Atasoy, \& Güveli, 2011). Teachers were asked to explain their thoughts with metaphors to understand more easily, classify, and draw conclusions. In the online teaching process, teachers' thoughts concerning the process are important in understanding this process. For this reason, this study aims to reveal what kind of phenomenon online mathematics teaching is, from the perspective of mathematics teachers, in light of the metaphors expressed by them.

While it is difficult to find metaphorical studies, which is the method used in this research, in online education, there are even less when it comes to the teaching of mathematics. At this point, in order to understand the process, it is important to see the point of view of the teachers, who have one of the leading roles in the process.

\section{Method}

Research Design

Online education has become a usual consequence of the pandemic today, and this shows that the entire world is united in this emergency. Therefore, the pandemic process has started a new era for all occupational groups. One of the occupational groups most affected by 
this process is teaching. It is believed that the thoughts provided by the teachers who have experienced the process, to facilitate and develop this process, and to identify any deficiencies can help them achieve these goals. Therefore, the research seeks an answer the question "What kinds of metaphors do teachers produce to describe online mathematics teaching?". For this reason, the preferred design of the research was the phenomenology, which is one of the qualitative research methods (Creswell \& Poth, 2018). In this study, based on the experiences of the participants, their ideas regarding a particular phenomenon were collected through metaphors. The phenomenon in this study is defined as the thoughts of teachers concerning online mathematics teaching.

\section{Participants}

Since the research aims to reveal thoughts about mathematics teaching processes, in particular, the participants targeted were classroom teachers; secondary and high school mathematics teachers who experience online teaching themselves. The data was collected in the 2020-2021 academic year, when distance education was followed during the pandemic process. Forty-three teachers participated in this research. The mean of students in the classes of the teachers participating in the research was approximately twenty-three, with the average age of the students being seventeen. The data shows that $58.1 \%$ of the teachers participating in the research did not receive any training on online education.

Data for the research was obtained from teachers who could be reached by the snowball method (Johnson, 2014). This method starts by establishing a connection with one of the units in the universe and continues by contact with another person, and then with another contact in the same way. Therefore, the sample is enlarged as a snowball effect (Gürbüz \& Şahin, 2018). Participation in the research was voluntary. In the form completed by the participants, there is specific information to be used in the research, and their participation in the research shows that they consent to the use of this information. In addition, a paragraph is presented to the participants, briefly explaining the purpose of the research and informing them that the participation is voluntary, that the data obtained from the participants will not be shared with anyone, and that names will not be shared if the analyzed data is shared for scientific purposes. It was also be emphasized that participation is voluntary in the text, which includes the link of the research questionnaire to be conveyed to other teachers by the snowball method. First, the implementation of the questionnaire was started 
with the teachers recognized by the researchers, and then the number of participants was increased.

\section{Data collection}

In this study, the questions created to reveal the metaphors of teachers on online education were sent to teachers. In this form, the questions were answered in ten subheadings, such as methods, classroom management, evaluation, and feedback, allowing teachers to reflect on the subject of 'Metaphorically examining the thoughts about online mathematics teaching', These questions were prepared in the form of 'Online teaching is similar to......, because....... Figure 1 contains sample questions from the relevant form.

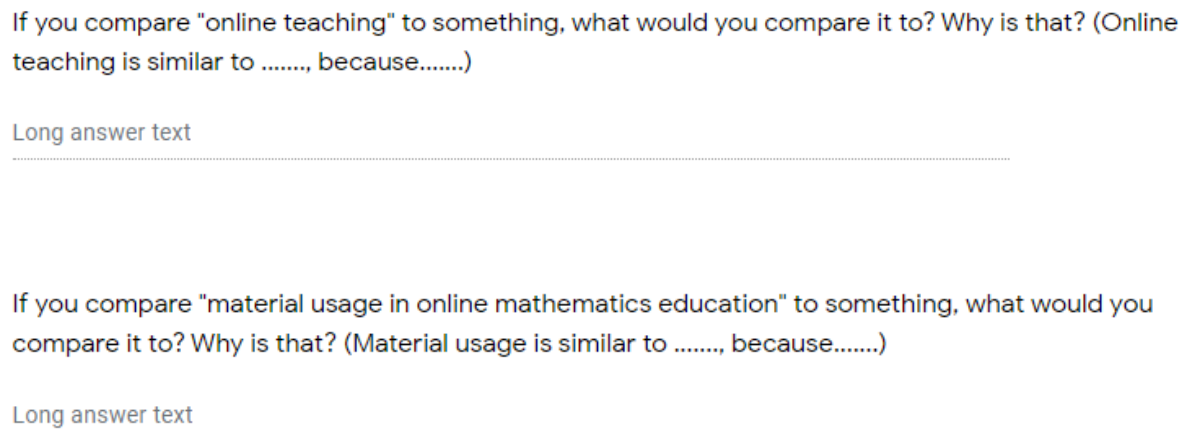

Figure 1. Sample questions from the relevant form

The form used was prepared by the researchers considering the main elements, such as planning and evaluation in the education process and sub-elements like the use of materials and feedback. After the first draft of the form used was prepared, four experts working in the field of mathematics education were consulted to obtain expert opinion. According to the opinions received, the content remained unchanged, and the form was finalized after making minor adjustments, such as adding words to increase the clarity of expressions, and adding a sample answer format to the beginning of the form to show the desired answer format. The final version of the form was applied to a teacher and a pilot application was made. At the end of the pilot application, the option not to write the answers in the questions was removed, and it became mandatory to answer all the questions.

Data Analysis 
Metaphors are used to express the similarity and relationship between two elements that cannot be fully explained with basic explanations (Güneş \& Firat, 2016). For this reason, frequency tables were created by listing the metaphors used by the participants, and the data was presented by grouping them thematically. In addition to this, the aim was also to present examples of teachers' statements and data qualitatively. Ethical permission (permission numbered 04.02.2021-1110) was obtained from Human Research Ethics Committee of the university where the authors are affiliated.

\section{Findings and Discussion}

According to the results of the survey, the participants created twenty-seven different metaphors and twenty-three different reasons to describe online mathematics education as well as ten sub-questions related to planning, resource use, materials, methods, classroom management, assessment, feedback, and professional development. A total of 309 answers were given for ten questions. The metaphors of the teachers' concerning online education and their thoughts on different sub-dimensions in the online education process were examined separately.

\section{Online Education}

Out of forty-three answers to this question, forty-two valid metaphors were produced and thirty-nine valid reasons were written. Forty-two valid metaphors for this sub-question are categorized as follows: profession group (f:3); situation (f:4); emotion (f:3); living person (f:1); music (f:1); health (f:1); sports (f:5); food (f:5); equipment (f:5); process (f:4); TV (f:3); game (f:2); nature (f:2); and phenomenon (f:2), as classified in fourteen different ways. Thirty-nine valid reasons for this sub-question are classified as follows: lack of interaction/communication (f:13); novelty (f:1); the difficulty of the process (f:3); versatility (f:3); use in necessity (f:2); insufficiency (f:1); need to progress in a certain program (f:1); variety (f:2); asking for mastery (f:4); because it is from the screen/remote (f:3); not achieving the desired result (f:1); the process requires interaction (f:2); being future (f:1); being a new process (f:1); and being life itself (f:1).

The most common reason for this sub-question is a lack of interaction/communication. This reason is explained through connection with metaphors; situation (f:4), emotion (f:2), health, sports (f:2), nature, food, equipment, and phenomenon (f:1) by participants. For example, P3 describes this reason with the metaphor 'situation' and expresses it as follows: 
"It is similar to flying a kite with a fan in the windless air, because when it is not done faceto-face, the interaction is not enough and the teaching remains artificial." P4 connects the same reason with the metaphor 'emotion' and says, "The orchestra must have the coordination and equipment to play, direct, and sing. You need to understand quickly, understand what the other person understands, or reach the maturity and practice of communication that will explain what you do not understand."

\section{Online mathematics education}

Out of forty-three responses to this sub-question, thirty-seven valid metaphors were produced and thirty-five valid reasons were written. Thirty-seven valid metaphors created for this sub-question are categorized as follows: fairy tale (f:1); toy (f:1); nature (f:2); action (f:3); vehicle (f:1); profession group (f:2); tool (f:2); emotion (f:3); food (f:5); process (f:2); object (f:1); activity (f:1); situation (f:6); game (f:2); sport (f:2); phenomenon (f:2); and livinganimal (f:1). The thirty-five valid reasons for this sub-question are categorized as follows: the process is difficult (f:10); there is no interaction/communication (f:7); the desired result is not achieved (f:6); it is necessary to progress in a certain program (f:5); it is versatile (f:2); there is progress (f:1); uncertainty (f:1); it is from screen/remote (f:1); and unlimited (f:2).

The most expressed reason in the answers given to this question by the participants is that the process is difficult. This reason is expressed by the participants by the following metaphors; action (f:2), emotion (f:3), situation (f:2), food, sports, and living. For example, P5 expresses this reason using the metaphor of action, saying, "It is like dressing an octopus that takes off its jacket from its arms that you always wear; it is difficult to be complete with everything." P32 says, "It is like cooking without taste, yes, but you need to be experienced," by using a situation metaphor. P42 states, "Online mathematics teaching is like a turtle, because writing the answers to the questions step-by-step with the help of the mouse causes a great waste of time," and associates this reason with a living metaphor. $\mathrm{P} 4$, on the other hand, uses the metaphor of nature to explain the reason 'the desired result is not achieved' by saying, "Online mathematics education is similar to the winter sun, it illuminates but does not heat. In other words, the desired and expected results are not achieved, unfortunately, especially at primary school level."

Planning in online education 
Out of forty-two answers given to this sub-question, thirty-one valid metaphors were produced and twenty-nine valid reasons were written. Thirty-one valid metaphors created for this sub-question are categorized as follows: activity (f:5); phenomenon (f:1); situation (f:6); structure (f:1); food (f:8); tool (f:5); nature (f:1); process (f:1); living-structure (f:1); action (f:1); and emotion (f:1). The twenty-nine valid reasons for this sub-question are categorized as follows: needing to progress in a certain program (f:6); being versatile (f:2); not achieving the desired result (f:3); the process being difficult (f:4); being accessible (f:1); supportive (f:2); the process requires interaction (f:1); and it is uncertain (f:1). An answer has been put into two different categories.

The most expressed reason in the answers given to this question by the participants is the need to progress in a certain program. This reason is expressed by the participants with certain metaphors; activity (f:3), phenomenon, structure, food (f:5), equipment (f:3), nature (f:1), and action (f:1). In one answer, no metaphor is specified. For example, P7 uses the metaphor of structure to say, "I compare this sub-question to the foundation of a building. If there is no preparation, the strength of the building you built on is questioned. The better the preparation phase, the more efficient the lesson will be." On the other hand, P17 expresses using the activity metaphor, "It aims to arrange the stages of preparation for the dance show, studying the movements, making the right moves with music at the right time and completing the choreography. In mathematics teaching, it will be difficult to learn without preparation, planning, and using the right method at the right time." P5 uses the situation metaphor and connects it with the reason the process is versatile saying, "It is like driving a car in an area where road construction works are constantly being done, you must have both $B, C, D$ plans and know how to drive." However, P34 with the situation metaphor expresses, "Planning is like life in online mathematics teaching, because you never encounter the results in your usual plans."

Using resources (pressed, technological, and others) in online education

Out of forty-three responses to this sub-question, twenty-eight valid metaphors were produced and twenty-nine valid reasons were written. Twenty-eight valid metaphors created for this sub-question are categorized as follows: tool (f:5); phenomenon (f:2); food (f:6); movie-story character (f:2); mission (f:1); process (f:3); vehicle (f:1); activity (f:1); feeling (f:1); living-animal (f:1); action (f:2); TV (f:1); living-person (f:1); and structure (f:1). The twenty-nine valid reasons for this sub-question are categorized as follows: being accessible 
(f:9); need to progress in a certain program (f:5); being supportive (f:3); asking for mastery (f:1); insufficient (f:1); novelty (f:1); using in only necessity (f:1); mandatory step (f:3); being limited (f:1); being a new process (f:1); not achieving the desired result (f:1); and difficult process (f:1). One answer was put into two different categories.

The most expressed reason in the answers given to this question by the participants is that it is accessible. This reason is expressed with the following metaphors; phenomenon (f:1), movie-story character (f:2), vehicle (f:1), food (f:2), process (f:1), tool (f:1), and living (f:1) by the participants. For example, P19 uses the food metaphor for this reason and says, "It is like a ready meal because everything is at hand, you are just transferring." P13 uses the movie-story character metaphor and expressed it as, "There is a character named $\mathrm{Mr}$ Talented. He has a truck, all the materials for the event are easily accessible." $\mathrm{P} 7$, on the other hand, expresses using resources in online education and is supportive over the structuring metaphor saying, "It is similar to the columns we set up on the resource building in online mathematics teaching. The more columns we have, the more diverse resources we use, the stronger our building will be." With the same feature and mission metaphor, P14 says, "The resource in online mathematics teaching is similar to the support team of the F1 pilot, because getting support from different sources in the course makes the teacher strong and completes his deficiencies."

\section{Material usage in online education}

Thirty-two valid metaphors were generated out of forty-three responses to this subquestion and thirty-one valid reasons were created. Thirty-two valid metaphors created for this sub-question are categorized as follows; situation (f:4); tool (f:9); living-animal (f:2); TV (f:2); process (f:1); action (f:2); activity (f:1); game (f:2); phenomenon (f:2); food (f:3); nature (f:1); living-person (f:1); movie-story character (f:1); and music (f:1). Thirty-one valid reasons for this sub-question are categorized as follows: being supportive (f:7); being versatile (f:4); providing convenience (f:3); not achieving the desired result (f:3); lack of interaction/communication (f:3); insufficient (f:3); being a new process (f:1); needing to progress in a certain program (f:3); variety (f:2); there is progress/improvement (f: 1); and being a mandatory step (f: 2). One answer was put into two different categories.

The most cited reason in the answers given to this question by the participants is that the use of materials in online mathematics teaching is supportive. Used metaphors for this reason by the participants are; situation (f:1), process (f:1), tool (f: 2), and music (f:1). No metaphor 
was cited in the two answers. For example, P3 expresses using the situation metaphor saying, "It is like filling up the vehicle's tank while driving on a long drive. Because the tank of the vehicle is full, you can drive your vehicle comfortably." On the other hand, P42 expresses by using the metaphor of music saying, "Using materials in online mathematics teaching is like moving music, because the students' interest in the lesson increases with the use of materials." The participants stated that using material is supportive. P9 claims that material usage is versatile by using the living metaphor saying, "Octopus. Because it is necessary to run both mouse, graphic tablet, chat screen, chat groups, and z-books at the same time." P12 uses the TV metaphor while expressing the inadequacy of material usage saying, "It may be watching movies from a TV that is not equipped with multidimensional movies. "

\section{Methods in online mathematics education}

Thirty-one valid metaphors were generated out of forty-three responses to this subquestion and twenty-eight valid reasons were created. Thirty-one valid metaphors created for this sub-question are categorized as follows: action (f:5); tool (f:4); game (f:3); food (f:4); institutional structure (f:2); activity (f:3); process (f:1); feeling (f:2); nature (f:1); feel (f:1); sense (f:1); living-organ (f:1); living-person (f:2); and phenomenon (f:1). Twenty-eight valid reasons for this sub-question are categorized as follows: being supportive (f:9); being a mandatory step (f:2); achieving the desired result (f:2); needing to progress in a certain program

innovation (f:1); being accessible (f:1); being insufficient (f:2); variety (f:3); the process being difficult (f:1); the process requiring interaction (f:1); no interaction/communication (f:1); not achieving the desired result (f:1); to be used in necessity (f:1); and to be a new process (f:1). Two answers were put into two different categories.

The most expressed reason for the answers given to this question by the participants is that the methods are supportive in online mathematics teaching. For this reason, the participants used the following metaphors; tools (f:2), action (f:2), activity, process, and feeling. No metaphor was stated in two answers. For example, K4 supports using the metaphor tool for this reason: "I compared the methods to traffic lights. It would express where and when we should do what", and K14 with the same metaphor says, "The methods used in online mathematics teaching are similar to a road map; navigating according to the determined method will make us reach the goals we marked on the map more effectively and easily. " In addition to being supportive, K29, using the activity metaphor, states the variety of 
methods in online education saying, "Similar to painting because it can achieve different results using different techniques." $\mathrm{K} 42$, on the other hand, states that it was a new process using the sense metaphor saying, "The methods used in online mathematics teaching are like discovering new tastes, because we start to learn a new technological application every day." Classroom management in online education

Out of forty-three answers to this sub-question, twenty-seven valid metaphors were produced and thirty-one valid reasons were created. Twenty-seven valid metaphors created for this sub-question are categorized as follows: profession group (f:3); TV (f:1); process (f:3); structure (f:1); press (f:2); tool (f:2); living-animal (f:1); activity (f:3); situation (f:4); action (f:3); object (f:1); living-person (f:1); nature (f:1); and movie-story character (f:1). Thirty-one valid reasons for this sub-question are categorized as follows: asking for mastery (f:7); need to progress in a certain program (f:6); the process is difficult (f:6); lack of interaction/communication (f:5); because it is from screen/remote (f:3); being versatile, being supportive (f:2); being a new process (f:1); variety (f:1); and being a mandatory step (f: 1 ). Three responses were put into two different categories.

The most expressed reason for the answers given to this question by the participants is that classroom management demands mastery in online mathematics teaching. For this reason, the participants used the following metaphors; profession group (f:2), TV (f:1), living (f:2), and activity (f:1). In one answer, no metaphor is stated. For example, K3 uses the professional metaphor saying, "It is like being a conductor. Because class management, which is a serious problem even in face-to-face education, requires online expertise." $\mathrm{K} 20$, without using metaphors says, "Limited, because it is difficult for the person who teaches the lesson to dominate the class. Even if the student concentrates elsewhere at that moment, it is difficult to take precautions." $\mathrm{K} 17$, on the other hand, uses the activity metaphor saying, "This is that the partners in the dance manage each other and the area they dance, while at the same time keeping the audience's attention on them. In classroom management, not only the teacher manages the classroom, but the students are actually in charge. The stage is for students, not for teachers." They explain that classroom management demands mastery in online education. $\mathrm{P} 27$, on the other hand, uses the metaphor of the situation to explain that there is no interaction/communication in classroom management saying, "Class management is like space. It is difficult to communicate with the students." 
Out of the answers given to this sub-question, twenty-five valid metaphors were produced and twenty-one valid reasons were created. Twenty-five valid metaphors created for this subquestion are categorized as follows: food (f:3); action (f:5); tool (f:2); mathematics operation (f:2); situation (f:4); activity (f:2); object (f:1); game (f:1); sport (f:1); phenomenon (f:1); process (f:1); institutional structure (f:1); and emotion (f:1). Twenty-one valid reasons for this sub-question are categorized as follows: not achieving the desired result (f:6); uncertainty (f:5); being a difficult process (f:4); needing to progress in a certain program (f:3); insufficient (f:2); lack of interaction/communication (f:1); and achieving the desired result (f:1). One answer was put into two different categories.

The most expressed reason in the answers given to this question by the participants is that the desired result is not obtained in evaluating online mathematics education. This reason is represented by the following metaphors used by the participants; mathematics operation (f: 2 ), phenomenon (f:1), tool (f:1), institutional structure (f:1), and emotion (f:1). For example, P13 uses the mathematical operation metaphor stating that, "The evaluation phase cannot be experienced sufficiently. I thought of doing a lot of work and multiplying the result obtained by $0 . "$ P36 uses the tool metaphor explaining that the desired result could not be achieved while assessing the situation saying, "The lid that does not fit the pot." $\mathrm{K} 3$, using the metaphor of food to explain that the process is difficult says, "It is like losing your sense of smell and taste while thinking that you are making a very good soup, because it is difficult to evaluate that nice-looking soup that you cannot smell and taste." While explaining the uncertainty of the process with the action metaphor K4 says, "Evaluating is like looking inside a closed box; is there treasure hidden in it or ordinary things?". K16, on the other hand, uses the situation metaphor for the versatility of evaluation in online education saying, "Evaluating online mathematics education can be like a tree climbing competition in which a monkey and a cow participate, because you may encounter unfair situations."

\section{Giving feedback in online mathematics education}

Out of forty-three answers given to this sub-question, twenty-nine valid metaphors were produced and twenty-four valid reasons were created. Twenty-nine valid metaphors created for this sub-question are categorized as follows: situation (f:3); action (f:6); game (f:1); press (f:2); sports (f:2); food (f:5); sense (f:2); vehicle (f:1); process (f:2); activity (f:2); phenomenon (f:1); nature (f:1); and tool (f:1). Twenty-four valid reasons for this sub-question are categorized as follows: being supportive (f:7); lack of interaction/communication (f:5); not 
achieving the desired result (f:4); achieving the desired result (f:2); insufficient (f:2); variety (f:1); being a mandatory step (f:2); being versatile (f:1); and requiring progress in a certain program (f:2). Two answers were put into two different categories.

The most expressed reason for the answers given to this question by the participants is that giving feedback in online mathematics teaching is supportive. The participants used the following metaphors for this reason; tool (f:1), activity (f:1), food (f:1), process (f:1), press (f:1), and action (f:2). For example, with the tool metaphor P13 says, "Giving feedback in online mathematics teaching is like gasoline; thanks to the feedback students gain speed and become motivated." P17 with the activity metaphor says, "This is the applause at the end of the dance show. Applause can be given in any case, good or bad, of course. The strength of the applause and the facial expressions of the applause can be understood. The student always expects feedback. He wants to hear feedback, not only at the end of the lesson or in the homework he has done, but in every topic that he tells his teacher, every question he asks, and every subject he talks about. The most important step for the student is feedback. Giving feedback in mathematics teaching is keeping the pulse of the student." P43 with the action metaphor says, "Giving feedback in online mathematics teaching is similar to earning points from shopping, because students' awareness of their learning increases with the feedback they receive at regular intervals and contributes to their success." The participants explain that giving feedback is supportive of using their sentences. K3 states the situation metaphor saying, "It is similar to trying to enter through the window while the door is standing. Because even one glance in face-to-face teaching is superior to much online feedback." P6, using the press metaphor says, "Radio broadcast is a good example of online training, where one-sided narrative-based feedback is not provided. Discussing a topic by improving the conversation in the telephone conversation can also be an example of giving feedback." They state that there is no interaction/communication in giving feedback with their sentences.

\section{Professional development in online education}

Out of forty-three answers to this sub-question, twenty-seven valid metaphors were produced and twenty-seven valid reasons were created. Twenty-seven valid metaphors created for this sub-question are categorized as follows: object (f:1); sport (f:2); situation (f:2); game (f:2); nature (f:4); process (f:5); activity (f:1); tool (f:1); profession group (f:2); food (f:1); movie-story character (f:1); living-animal (f:2); phenomenon (f:1); action (f:1); and vehicle (f:1). Twenty-seven valid reasons for this sub-question are categorized as follows: there is progress/improvement (f:11); not achieving the desired result (f:3); being a new process (f:5); 
the process being difficult (f:3); achieving the desired result (f:2); asking for mastery (f:1); it will be used in necessity (f:1); and to progress in a certain program (f:1).

The most cited reason in the answers given to this question by the participants is that their professional development is in progress in online mathematics teaching. This reason is expressed with the following metaphors by the participants; nature (f:3), process (f:2), activity (f:1), occupation group (f:1), living (f:1), and vehicle (f:1). No metaphor was specified in the two answers. For example, P14 with the metaphor of nature says, "My development in online mathematics teaching is similar to the growth phase of a sapling; as the sapling is watered, I gain experience and improve myself through reading." P16 with the process metaphor says, "I cannot deny the contribution of online education to my professional development, while I think that I cannot make much progress." With the metaphor of nature P42 says, "My development in online mathematics teaching is similar to a sapling because, with developing technology, I have to learn many programs to make the lessons more interesting. Like a sapling growing every day, my professional knowledge grows." By establishing their sentences, these participants state that their personal development is in progress/development. $\mathrm{P} 3$, on the other hand, says, "It looks like a pit where sand is constantly thrown and never fills, because I think I was never complete." P3 emphasizes that the desired result is not achieved by constructing the sentence.

When the answers to all the questions given by the participants are examined holistically, summary information about the metaphors is presented in Table 1. The metaphors shown in the table are all of the metaphors the participants created for the ten questions in the questionnaire.

Table 1: Frequency table of the metaphors

\begin{tabular}{lclc}
\hline \multicolumn{1}{c}{ Metaphor } & Frequency (f) & \multicolumn{1}{c}{ Metaphor } & Frequency (f) \\
\hline 1. Mission & 1 & 15. Profession group & 10 \\
2. Fairytale & 1 & 16. Feeling & 12 \\
3. Toy & 1 & 17. Sport & 12 \\
4. Health & 1 & 18. Nature & 13 \\
5. Mathematical operation & 2 & 19. Phenomenon & 13 \\
6. Music & 2 & 20. Game & 13 \\
7. Sense & 3 & 21. Living & 15 \\
8. Institutional structure & 3 & 22. Activity & 19 \\
9. Structure & 3 & 23. Process & 23 \\
10. Vehicle & 4 & 24. Action & 28 \\
11. Press-publication & 4 & 25. Situation & 33 \\
12. Film-Tale character & 5 & 26. Tool & 36 \\
13. Object & 5 & 27. Food & 40 \\
14. TV & 7 & Total & 309 \\
\hline
\end{tabular}

Necatibey Eğitim Fakültesi Elektronik Fen ve Matematik Eğitimi Dergisi

Necatibey Faculty of Education, Electronic Journal of Science and Mathematics Education 
As can be understood from the table, the most common metaphor is 'food'. This metaphor, which corresponds to $13 \%$ of the metaphors, was used forty times by the participants. The second most frequently repeated metaphor is 'tool'. It was used thirty-six times by the participants in different questions and equals $11.6 \%$ of all of the metaphors. The least used metaphors are 'mission', 'fairy tale', 'toy', and 'health'. These metaphors are only used once and equal to $0.3 \%$ of the total metaphors. Table 2 presents the reasons stated by the participants regarding the metaphors they produced holistically. The explanations shown in the table are the statements created by the participants for all ten questions in the questionnaire.

Table 2: Frequency table for the reasons for metaphors

\begin{tabular}{|c|c|c|c|}
\hline Reasons & $\begin{array}{l}\text { Frequency } \\
\text { (f) }\end{array}$ & Reasons & $\begin{array}{l}\text { Frequency } \\
\text { (f) }\end{array}$ \\
\hline 1. Variety & 1 & 13. Being accessible & 10 \\
\hline 2. Because it is the future & 1 & 14. Being a new process & 10 \\
\hline 3. Being life itself & 1 & 15. Being a mandatory step & 10 \\
\hline 4. Unlimited & 2 & 16. Insufficient & 11 \\
\hline 5. Providing convenience & 3 & 17. Being versatile & 13 \\
\hline 6. Novelty & 3 & 18. Asking for mastery & 13 \\
\hline $\begin{array}{l}\text { 7. The process requires } \\
\text { interaction }\end{array}$ & 4 & 19. Not achieving the desired result & 29 \\
\hline 8. It will be used in necessity & 5 & 20. Being supportive & 30 \\
\hline $\begin{array}{l}\text { 9. Because it is from the } \\
\text { screen/remote }\end{array}$ & 7 & 21. The process is difficult & 32 \\
\hline $\begin{array}{l}\text { 10. Achieving the desired } \\
\text { result }\end{array}$ & 7 & $\begin{array}{l}\text { 22. Lack of interaction } \\
\text { /communication }\end{array}$ & 36 \\
\hline 11. Uncertainty & 8 & $\begin{array}{l}\text { 23. Need to progress in a certain } \\
\text { program }\end{array}$ & 46 \\
\hline $\begin{array}{l}\text { 12. There is progress } \\
\text { /improvement }\end{array}$ & 8 & Total & $295-10=285$ \\
\hline
\end{tabular}

When the responses of the participants to all of the questions are examined, a total of 295 explanations were created. However, ten of the answers are categorized into two different categories, meaning there are 285 answers for the reasons for using metaphors in the answers. Among the 295 explanations, the most common explanation is 'requiring progress in a certain program', which is used forty-six times equaling $15.6 \%$ of all of the answers. It is followed by the explanation 'lack of interaction/communication' which was expressed thirty-six times (12.2\%), 'being a difficult process' thirty-two times (10.8\%), 'being supportive' thirty times (10.2\%), and 'not achieving the desired result' twenty-nine times (9.8\%). The least emphasized reasons are 'diversity in the process', 'it is a future', and 'it is life itself'. These reasons were only stated once. 


\section{Conclusion and Suggestions}

This research aims to determine what metaphors are in teachers' thoughts regarding online mathematics teaching. In the literature, general information concerning online education, which has become prominent in our lives, is in a minority of studies that include the opinions of people who are affected by online education. There is a scarcity of studies on the opinions of teachers, and the literature is extremely limited when the subject is focused on mathematics teachers. A condition of participation in the survey conducted was that the participants had personally experienced online mathematics education. The survey consisted of ten subquestions regarding online mathematics education and planning, resource use, materials, methods, classroom management, assessment, feedback, and professional development. These survey questions require answering through a metaphor and explaining the reason for using this metaphor. Twenty-seven different metaphors and twenty-three different reasons were created by the participants. Different participants created different metaphors for the same sub-question and gave different reasons, even if they had created the same metaphor. From this, it is possible to say that it is impossible to explain online education and its sub-headings using a single metaphor, and that the same term may evoke different reasoning for different people.

According to the results, the most used metaphor is 'eating', with forty repetitions. The metaphor of 'meal' is followed by 'tools' with thirty-six repetitions and 'situation' with thirty-three repetitions. These numbers were determined from 309 responses to ten questions. The most used explanations of the reasons for the use of these metaphors are as follows: 'need to progress in a certain program in online education' (f:46); 'lack of interaction/communication in the process' (f:36); 'difficult process' (f:32); and 'supportive' (f:30). As can be seen from the explanations given for the reasons for using metaphors, the majority of the teachers participating in the research had negative views of online education, with the most important reasons being, 'lack of interaction/communication' (f:36), 'the process is difficult' (f:32), and 'not achieving the desired result' (f:29). Although teachers with positive attitudes are in a minority, the reasons they show are; it has been classified as 'supportive' (f:30), 'accessible' (f:10), 'obtaining the desired result' (f:7), and 'facilitating' (f:3). Apart from the positive and negative answers given by the teachers, the interesting part is that a number of the teachers looked at the process temporarily and said that this process was a mandatory step, or that it would only be used in necessity. Certain teachers had 
difficulty in adapting to the process even over time, and could not integrate online education into the normal teaching process.

Tuncer and Bahadir's (2017) study evaluates the indifference and insincerity of instructors, saying that this process is considered to be a cold environment by the students and that faceto-face education is preferred. They also emphasize that online education is supportive as it allows learning in the environment and review when desired. In a study by Karakuş, Ucuzsatar, Karacaoğlu, Esendemir, and Bayraktar (2020) a restriction is noted in the relationship between teacher-student in the online education process, and that the relationship between student-student and student-teacher is not the same as in face-to-face education. In addition, in research conducted by Sümer (2016), students support the explanation that there is no interaction/communication in the process, which was repeated thirty-six times during the research, for reasons such as providing the interaction in the online course in written form and not making eye contact with the teacher.

Gürsul and Keser (2009), in their study with forty-two students, argue that contrary to the findings of the research, online education is more successful than face-to-face education in group work. Corner (2020), on the other hand, talks about students turning off their cameras and only listening to the lesson, making classroom management more difficult and affecting teachers' well-being. This research shows the difficulty of the process in general. Ilgaz (2014) finds that the fact that lessons are recorded and accessible afterwards is helpful for students who missed the course content while taking notes in face-to-face lessons and argue that this is supportive in terms of education. Karasar (2004) similarly argues that online education brings convenience and supports education. Although metaphors containing negative thoughts are prevalent in this study, metaphors involving positive perspectives also overlap with the findings of these studies.

The results of this research can be used in the organization of in-service seminars given to teachers, the preparation of content, and the creation of models for online mathematics education, as they will provide clues concerning teachers' thoughts on the process, deficiencies of the process and how it can be improved. In addition, this research can direct researchers to more detailed research on the subject; for example, 'How were different grade levels affected by this process?'. Another benefit of the study for researchers is that it allows comparison of the thoughts on online teaching shown in this research with thoughts on nononline face-to-face lessons. 
In addition to researchers, it can also offer teachers the opportunity to repeat the process for themselves and to look at their teaching practices in light of their thinking. This type of practice can also provide opportunities to improve their teaching practices indirectly. There are a number of studies regarding the online teaching process of teachers in the field, the pandemic process, an epidemic or online education. It is clear that much more work is needed on the quality of the education received, the deficiencies of the education and measures that can be taken in this regard.

\section{Çevrimiçi Matematik Öğretimi Üzerine Yansıtıcı Düşünceler}

\section{Özet:}

Değişen dünya ve gelişen olaylar ile birlikte çevrim içi öğretim gündemimizin en önemli başlıklarından biri haline gelmiştir. Çevrim içi öğretimin etkililiği başlıca gerçekleştiricisi öğretmenler olan bazı temel unsurların gerçekleşmesi ile ilişkilidir. Çevrim içi eğitime geçiş süreci öğretmenler için de yeni bir öğrenme sürecidir. Öğretmenlerin yeni uygulamalara uyum sürecinde kendi öğrenmesiyle ilgili bulgular bunun öğretmenlerin yansıtıcı düşünceleri ile ilişsili olduğunu ortaya koymaktadır. $\mathrm{Bu}$ sebeple, bu araştırmanın sorusu “Öğretmenler, çevrim içi matematik öğretimine yönelik ne tür metaforlar üretmektedir?" şeklindedir. Araştırmanın deseni olgu bilim desenidir. Verilerin analizinde metafor analizi kullanılmıştır. Bu araştırmaya 43 öğretmen katılmıştır. Katılımcılar, çevrimiçi matematik eğitimi ile ilgili fikirlerini metaforlar kullanarak yansıtmışlardır. Katılımcıların düşüncelerinden 27 farklı metafor ve 23 farklı neden oluşturulmuştur, en çok kullanılan metafor "yemek" metaforu, en çok kullanılan iki açıklama ise "belirli bir programda ilerleme ihtiyacı" ve "süreçte etkileşim/iletişim yokluğu" olmuştur. Araştırma sonucunda öğretmenlerin çevrimiçi eğitim hakkında çoğunlukla olumsuz düşündükleri belirlenmiştir. 


\section{References}

Altıparmak, M., Kurt, İ. D., \& Kapıdere, M. (2011). E-öğrenme ve uzaktan eğitimde açık kaynak kodlu öğrenme yönetim sistemleri. XI. Akademik Bilişim Kongresi, 4-5.

Arat, T. \& Bakan, Ö. (2011). Uzaktan eğitim ve uygulamaları. Selçuk Üniversitesi Sosyal Bilimler Meslek Yüksekokulu Dergisi, 14( 1-2), 363-374.

Baki, A., Karal, H., Çebi, A., Şılbır, L., \& Pekşen, M. (2011). Uzaktan eğitimde öğretim yönetim sistemi ve senkron eğitim platformu tasarim süreci: KTÜ örneği. Türk Bilgisayar ve Matematik Ĕgitimi Dergisi, 1(1). 85-101.

Creswell, J. W., \& Poth, C. N. (2016). Qualitative inquiry and research design: Choosing among five approaches. Sage.

Çakmak, Ö. (2008). Eğitimin ekonomiye ve kalkınmaya etkisi. Dicle Üniversitesi Ziya Gökalp Ĕ̈itim Fakültesi Dergisi, 11, 33-41.

Duban, N. \& Şen, F. G. (2020). Sınıf öğretmeni adaylarının Covid-19 pandemi sürecine ilişskin görüşleri. Electronic Turkish Studies, 15(4). 357-376.

Elçil, Ş. \& Şahiner, D. S. (2014). Uzaktan eğitimde iletişimsel engeller. Sosyal ve Beşeri Bilimler Dergisi, 6(1), 21-33.

Gursul, F. \& Keser, H. (2009). The effects of online and face-to-face problem-based learning environments in mathematics education on student's academic achievement. ProcediaSocial and Behavioral Sciences, 1(1), 2817-2824.

Güneş, A. \& Fırat, M. (2016). Açık ve uzaktan öğrenmede metafor analizi araştırmaları. Açıöğretim Uygulamaları ve Araştırmaları Dergisi, 2(3), 115-129.

Gürbüz, S. \& Şahin, F. (2018). Sosyal bilimlerde araştırma yöntemleri. Ankara: Seçkin Yayınc1lı.

Güveli, E., İpek, A. S., Atasoy, E. \& Güveli, H. (2011). Sınıf öğretmeni adaylarının matematik kavramına yönelik metafor algıları. Türk Bilgisayar ve Matematik Eğitimi Dergisi, 2(2), 140-159.

Fırat, M., Kabakçı-Yurdakul, I. \& Ersoy, A. (2014). Bir eğitim teknolojisi araştırmasına dayalı olarak karma yöntem araştırması deneyimi. Eğitimde Nitel Araştırmalar Dergisi, 2(1), 65-86.

Hilli, C. (2020). Distance teaching in small rural primary schools: A participatory action research project. Educational Action Research, 28(1), 38-52. 
Karakuş, N., Ucuzsatar, N., Karacaoğlu, M. Ö., Esendemir, N., \& Bayraktar, D. (2020). Türkçe öğretmeni adaylarının uzaktan eğitime yönelik görüşleri. Rumelide Dil ve Edebiyat Araştırmaları Dergisi, 19, 220-241.

Karasar, Ş. (2004). Eğitimde yeni ilitişim teknolojileri-internet ve sanal yüksek eğitim. The Turkish Online Journal of Educational Technology, 3(4), 117-125.

Ilgaz, H. (2014). Uzaktan eğitim öğrencilerinin eşzamanlı öğrenme uygulamalarında karş1laştıkları sorunlar ve çözüm önerileri. Eğitim Bilimleri ve Uygulama, 13(26), 187-204.

Kebritchi, M., Lipschuetz, A., \& Santiague, L. (2017). Issues and challenges for teaching successful online courses in higher education: A literature review. Journal of Educational Technology Systems, 46(1), 4-29.

Kocabıyık, O. O. (2015). Olgu bilim ve gömülü kuram: Bazı özellikler açısından karş1laştırma. Trakya Üniversitesi Eğitim Fakültesi Dergisi, 6(1), 55-66.

Küçükkömürler, S. (2017). Belirsizliğin psikolojik etkileri. Nesne-Psikoloji Dergisi, 5(10), 329- 344.

Levine, P. M. (2005). Metaphors and images of classrooms. Kappa Delta Pi Record, 41(4), $172-175$

Sümer, M. (2016). Sanal derslere ilişkin öğrenci görüşlerinin incelenmesi . Uşak Üniversitesi Sosyal Bilimler Dergisi, 9(27/3), 181-200.

Tahiroğlu, M. \& Çakır, S. (2014). İlkokul 4. Siniflara yönelik matematik motivasyon ölçeğinin geliştirilmesi. Ahi Evran Üniversitesi Kırşehir Eğitim Fakültesi Dergisi,15 (3), $29-48$.

Johnson, T. P. (2014). Snowball sampling: introduction. Wiley StatsRef: Statistics Reference Online.

Toker, Z. (2021). Perceiving the change in the process of adaptation to an international curriculum framework. Education and Science, 46(205), 93-111.

Tuncer, M. \& Bahadır, F. (2017). Uzaktan eğitim programlarının bu programlarda öğrenim gören öğrenci görüşlerine göre değerlendirilmesi. Journal of Educational Reflections, 1(2), 27-36.

Yenilmez K. \& Avcu T. (2009). Primary school students' difficulties in learning absolute value. Dicle Üniversitesi Ziya Gökalp Ĕ̈itim Fakültesi Dergisi, 12, 80-88. 